Review

\title{
The Vulnerability of Rice Value Chains in Sub-Saharan Africa: A Review
}

\author{
Fanen Terdoo* and Giuseppe Feola \\ Department of Geography and Environmental Science, University of Reading, Whiteknights, P.O. Box 227, \\ Reading RG6 6DW, UK; g.feola@reading.ac.uk \\ * Correspondence: fanenterdoo@gmail.com or hz811462@reading.ac.uk; Tel.: +44-750-197-2006
}

Academic Editors: Nir Y. Krakauer, Ajay K. Jha, Vishnu Pandey and Tarendra Lakhankar Received: 8 August 2016; Accepted: 12 September 2016; Published: 19 September 2016

\begin{abstract}
Rice is one of the most important food crops in sub-Saharan Africa. Climate change, variability, and economic globalization threatens to disrupt rice value chains across the subcontinent, undermining their important role in economic development, food security, and poverty reduction. This paper maps existing research on the vulnerability of rice value chains, synthesizes the evidence and the risks posed by climate change and economic globalization, and discusses agriculture and rural development policies and their relevance for the vulnerability of rice value chains in sub-Saharan Africa. Important avenues for future research are identified. These include the impacts of multiple, simultaneous pressures on rice value chains, the effects of climate change and variability on parts of the value chain other than production, and the forms and extent to which different development policies hinder or enhance the resilience of rice value chains in the face of climatic and other pressures.
\end{abstract}

Keywords: vulnerability; resilience; rice value chains; climate change; sub-Saharan Africa

\section{Introduction}

Rice is one of the most important food crops in Africa, where rice and the economic activities related to its production, processing, distribution, and consumption are widely considered a key for economic development, food security, and poverty reduction [1-3]. In most of sub-Saharan Africa (SSA), rice is the most-demanded staple food and the food product traded in the highest quantities [2,4]. The West African sub-region is regarded as the biggest rice market in SSA, accounting for two-thirds of the region's rice demand with $50 \%$ imports, which represents about $20 \%$ of the total volume of rice traded globally [5].

Following the advice of international organizations such as the World Bank and the International Monetary Fund, many governments in the region have implemented a liberalization of the agri-food sector, and have facilitated its opening to global markets as a strategy to increase competition, reduce food prices (especially in urban areas), and mitigate poverty [6,7]. However, the results of these policies have been contested, and while some studies have shown the benefits of agri-food liberalization policies, others have highlighted their disruptive effects and tendency to cause price fluctuation and volatility $[4,8]$.

Increasing climate variability and change have compounded the effects of this opening to global agri-food markets. In large parts of SSA, droughts, declining rainfall and water scarcity, flooding, and rising average temperatures have put pressure on domestic rice value chains $[9,10]$. The effects of climate change are projected to further aggravate value chains in the future $[9,10]$. However, while it is apparent that climate change represents a threat to rice value chains in SSA, less attention has been given to examining sub-regional variation and the patterns of effects of climate change along the value chains. 
Against this background, this paper examines existing evidence on the vulnerability of rice value chains to climate change and to the opening of global agri-food markets in SSA. It also identifies research needs for building resilience in the rice value chains. Specifically, with reference to SSA, this paper aims to: (i) characterize existing research on the vulnerability of rice value chains; (ii) synthesize the evidence on the vulnerability of rice value chains to climate change and economic globalization; and (iii) discuss agriculture and rural development policies and their relevance for the vulnerability of rice value chains. Thus, the project maps the literature on rice value chains in SSA at a time of ongoing debate about policies for strengthening the rice sector in this region and of growing stress posed by climate change.

\section{Theoretical Background and Methods}

\subsection{Theoretical Background and Definitions of Key Concepts}

Ericksen [11], Ingram [12], and Tendall et al. [13] reveal that food systems can be considered as social-ecological systems that consist of mutually interacting biophysical and social components. Food systems encompass the activities of food production, processing, distribution, retail, and consumption and involve multidimensional (e.g., social, economic, institutional, environmental, political, cultural) processes [13]. Food system components are embedded in place, and their processes are influenced by biophysical, social, economic, and political factors. At the same time, food systems can be examined in terms of their performance or ability to deliver selected outcomes, of which food security is a typical and highly relevant example [12]. As complex social-ecological systems [14,15] food systems are characterized by interactions among system components and among factors, processes, and outcomes. Such interactions are often non-linear, and are characterized by time and space lags and thresholds, which make it difficult to implement effective policies for promoting food security or food system sustainability. This highlights the need for whole-system analysis rather than the assessment of individual parts of the food system [13].

The concept of the food value chain (FVC) is used in this review in close relation to the concept of food systems. FVC can be defined, following Kaplinsky and Morris [16] (p. 4), as "the full range of activities which are required to bring a product or service from conception, through the different phases of production (involving a combination of physical transformation and the input of various producer services), delivery to final consumers, and final disposal after use". Thus, the notion of FVC emphasizes the process of economic value creation along the chain, and consequently bears a more direct connection with issues of economic development that have been central to SSA for decades, while retaining a system perspective that encompasses the complex socio-ecological dynamics that characterize food systems.

Various scholars and international organizations have identified the adoption of a system approach as key to improving the resilience of the rice sector and reducing its vulnerability (e.g., Ericksen [11], Steve and Kopainsky [17]. Tendall et al. [13] (p. 19) proposed the following definition of food system resilience: the "capacity over time of a food system and its units at multiple levels, to provide sufficient, appropriate and accessible food to all, in the face of various and even unforeseen disturbances". This definition ties resilience to a functional goal, thus excluding the possibility of defining resilient food systems that deliver undesirable outcomes. Moreover, this definition points out the multi-level nature of food systems. For example, resilience can occur from the individual to national food systems to international value chains. Finally, according to this definition, resilience is a gradable property of food systems; systems can be more or less resilient. Furthermore, resilience is a dynamic property. Rather than enabling the system to face one-off disturbances, resilience constitutes the system's capacity to minimize food insecurity in a changing environment with recurring disturbances [13]. Resilience is therefore not a static target, but a property in flux that results from reactive but also preventive actions and their feedback on system components over time [13]. 
As a large body of literature has shown, resilience and vulnerability are related (e.g., Gallopín [18], Miller et al. [19]). Vulnerability to a stressor is a function of sensitivity, exposure, and adaptive capacity [20]. Consistent with food security approaches, food system vulnerability can be measured not only in terms of food availability, but also of access and utilization [21,22]. This calls for a system perspective and for the examination of sources of vulnerability at different levels and in relation to different components of the food systems and their interactions, including production, storage, and distribution $[23,24]$. Resilient food systems are less vulnerable to stresses because they harbor the capacity to respond to disturbances and plan for change.

Both the resilience and vulnerability literature acknowledge that socio-ecological systems can be simultaneously exposed to multiple stressors, such as climate change and globalization, and that the stressors or their effects may interact to threaten the resilience and sustainability of those systems [24]. Several cases of agricultural and food systems under multiple exposures have been analyzed in the literature (e.g., Luers et al. [25]; Mertz et al. [26]; Feola et al. [27]; Feola et al. [28]). The literature shows that when different stressors are addressed in isolation, maladaptation is often observed. This is because measures to adapt to one stressor may be maladaptive to a different stressor. On the other hand, resilience is built and vulnerability is reduced through effective adaptation when multiple exposures are considered [29].

\subsection{Literature Selection}

A literature search was conducted in the following major databases: Web of Science, Science Direct, Scopus, Geobase, Google Scholar, Journal Storage (JSTOR), Social Science Research Network, and African Journal Online. In addition, literature was collected from online databases and websites of relevant institutions, conference proceedings, and non-governmental organizations, such as the West Africa Rice Development Association (WARDA), the African Rice Centre, the Food and Agricultural Organization (FAO), the International Rice Research Institute (IRRI), and the United States Agency for International Development (USAID). The following keywords were used in various combinations: "vulnerability", "impact", "rice value chain", "production", "processing", "distribution", "marketing", "consumption", "climate change", "economic globalization", "trade liberalization", "policy", and "sub-Saharan Africa". The search was limited to publications published from the year 2000 onwards.

A total of 334 publications were initially identified. The publications with a strong emphasis on agronomic practices, including systems of intensification and their efficiency, were then excluded from the analysis. The studies reviewed focused on the social, political, cultural, and economic dimensions of vulnerability, rather than the technical and agronomic dimensions. By applying these selection criteria, 55 articles were included in this review (Supplementary Materials).

\subsection{Analysis}

The analysis of the literature addressed three aspects, corresponding to the research questions driving this study. First, the selected literature was characterized by: (i) the type of disturbances considered (i.e., climate change, economic globalization or trade liberalization, and others); (ii) the component of the value chain investigated (i.e., production, processing, distribution, consumption); (iii) the sub-regional focus within SSA (i.e., East, West, Central, and Southern Africa); and (iv) the research methods employed (qualitative, quantitative, or mixed methods). Subsequently, the literature was analyzed to identify the impacts of the disturbances on rice value chains in SSA, and the policies recommended for rice sector development that are relevant for minimizing vulnerability and building the resilience of value chains. For these latter aspects, no predetermined analytical framework was adopted, as the analysis followed an emergent process of synthesis of the existing literature rather than the imposition of pre-determined conceptual schemes. 


\section{Results}

\subsection{Literature Characterization}

The reviewed literature allowed for the characterization of existing research on the vulnerability of rice value chains (RVCs) in SSA, as illustrated in Table 1.

Table 1. Number of papers that consider different types of disturbances, value chain components, and sub-regions and that employ different research methods.

\begin{tabular}{ccc}
\hline Criteria & & Number of Papers \\
\hline \multirow{3}{*}{ Disturbance } & Climate change & 16 \\
& Opening to global markets & 27 \\
& No climate change or market focus & 12 \\
\hline \multirow{3}{*}{ Value chain component } & Production & 26 \\
& Processing & 5 \\
& Distribution and marketing & 15 \\
& Consumption & 4 \\
& All components & 5 \\
\hline \multirow{2}{*}{ Sub-region } & East Africa & 14 \\
& Central Africa & 8 \\
& Southern Africa & 12 \\
& West Africa & 35 \\
Research methods & All sub-Saharan regions & 6 \\
& Quantitative & 37 \\
& Qualitative & 12 \\
\hline
\end{tabular}

In all studies reviewed, climate and economic disturbances were investigated separately, while a number of studies addressed aspects of the vulnerability of RVCs with no direct focus on either climate change or opening to global markets (Table 1).

The majority of studies on the vulnerability of RVCs to climate change in SSA are devoted to assessing the impacts on rice production. Similarly, the majority (27) of the studies on the impact of opening to global markets on RVCs focus on rice processing, distribution, and marketing, while little attention is given to assessing the impacts on other components of the RVCs, or on the RVCs as a whole. This marks a difference from studies on climate disturbances, which focus exclusively on production.

In terms of regional focus, the literature has mostly concentrated on West Africa (Table 1). Countries in this sub-region share a common history of traditional rice consumption [30] (Saito et al., 2014) and common trends of increasing demand for rice caused by rapid population, urban, and income growth, which is not matched by domestic production and distribution capacity [31,32]. Nigeria has the highest concentration of studies (16), while Burkina Faso (8), Ghana (8), Senegal (6), Benin (6), Tanzania (6), Madagascar (6), Niger (6), Cote d'lvoire (5), Uganda (4), Mali (5), and Togo (4) were also often researched. Most of these countries are importers of rice and have experienced severe impacts of the agri-food market opening on their domestic rice value chains [31].

Finally, the majority of the reviewed studies adopted a quantitative methodological approach. Quantitative methods included statistical and econometrics modeling that used secondary datasets or survey data, while qualitative methods included interviews (6) and policy analysis (12).

\subsection{Vulnerability of Rice Value Chains in Sub-Saharan Africa}

This section presents and discusses the results of the literature review on the vulnerability of rice value chains to climate change, variability, and economic globalization. 


\subsubsection{Rice Value Chains and Climate Change and Variability}

A number of studies have investigated the vulnerability of RVCs to climate change and variability (CCV) in SSA. While Knox et al. [33] argued that evidence of impacts of CCV on rice crop yields in Africa is contradictory, other scholars have advanced our understanding of the impacts of CCV in specific agri-food systems in SSA. This section synthetizes the findings of this review with a particular focus on observed and projected impacts of CCV on RVCs in SSA. The summary also examines the unevenness of these impacts, which helps shed light on the sources of RVCs' vulnerability.

CCV may influence agriculture in SSA mainly through rising temperatures, decreasing rainfall, and changes in $\mathrm{CO}_{2}$ concentrations (as they relate to carbon fertilization), atmospheric humidity, and solar radiation. The RVC literature has focused almost exclusively on estimating the effects of these CCV manifestations on rice production, at the expense of other RVC components such as processing, distribution, and consumption, which may equally be impacted by climate change and variability.

There appears to be agreement on the negative effects (observed or projected) of CCV. These include the reduction of usable area for cultivating floating rice in the face of increased demand for rice in the Inner Niger Delta [34]; the reduction in rice yield in Burkina Faso [35], Tanzania [36], West Africa [10], and across SSA [37]; the reduction of both rice yield and grain quality in Nigeria [38]; the decline of crop productivity with higher negative impacts on irrigated than rainfed production in South Africa [39]; and significant crop and income losses among smallholder farmers in Madagascar [40]. Most of these effects are associated with losses of arable lands, which can be observed in countries around the Sahel due to desertification and, in coastal and delta countries, due to the inundation of farmlands from frequent incidences of floods [35]. Furthermore, the increasing variability of rainfall, rising temperatures, and the increased frequency of droughts and water shortages have affected productivity, while the frequency of diseases and pest infestation as a consequence of different climatic conditions has compounded these problems, often resulting in reductions in both rice yield and grain quality in the region.

The factors that account for the negative impacts differ according to regions and countries. For example, in Madagascar (Southern Africa), Harvey et al. [40] found that extreme weather events such as cyclones, diseases, and pest infestations resulting from CCV were major causes of yield reduction. In Kenya (East Africa), on the other hand, Ochieng et al. [41] determined that changes in temperature have a greater impact on crop production than changes in rainfall. This is because rice production in Kenya is mostly irrigated. In Burkina Faso (West Africa), rice production is largely rainfed, and Kima et al. [35] found rainfall to be the most important factor for rice yield reduction.

The effects of changes in $\mathrm{CO}_{2}$ concentrations, atmospheric humidity, and solar radiation may be more mixed than those of rising temperatures and decreasing rainfall. Empirical evidence on rice production in Niger State, Nigeria suggests that increased relative humidity and minimum temperature have contrasting effects (negative and positive, respectively) on rice production [42]. Some studies identified impacts on revenue among smallholder farmers in Kenya [41] and dry land and irrigated rice farmers in Nigeria [43]. Other studies projected a slightly positive change in crop yield for six crops as a whole in SSA in 2030, with maize and rice in particular having slightly higher yields [44]. This is broadly consistent with the positive impact projected by Lobell et al. [45].

Thus, the impacts of climate change and variability are unevenly distributed, and their occurrence and intensity varies by geographical location, production system, and farmer characteristics. This unevenness sheds some light on the sources of vulnerability of RVC in SSA.

Lobell et al. [45] projected the impacts of precipitation and temperatures changes on crop production in SSA for 2030. In all four regions, namely Western, Central, Eastern, and Southern Africa, the study finds a positive impact for rice. On the other hand, Liu et al. [44] projected that, in 2030, rice in SSA will have a higher yield in Eastern and Southern Africa, but a lower yield in Central Africa. 
Regarding production systems, Ajetomobi et al. [43] found that in Nigeria, temperature increases will reduce net revenue for dry land rice farms, but revenue for irrigated farms is expected to increase. In the same vein, increases in precipitation will cause reductions in revenue for dry land rice farms but an increase for irrigated farms. In South Africa, on the other hand, Calzadilla et al. [39] found that higher temperatures and less rainfall will lead to a decline in crop productivity, with higher negative impacts on irrigated than rainfed production.

Finally, there seems to be agreement in the literature on the greater vulnerability of smallholders in SSA [38,40,41,43]. For example, Harvey et al. [40] found that smallholder rice, maize, and cassava farmers in Madagascar have been adversely impacted by the manifestations of CCV. These adverse effects are due to their high dependence on agriculture for their livelihoods, limited resources and capacity, isolation, and lack of access to state safety nets. Smallholders may have fewer options for diversifying their livelihoods and are sometimes found to be more affected by poor health, lack of access to land due to the traditional land tenure systems, lack of adequate water, low levels of technology and education, and institutional mismanagement (see Nyantakyi-Frimpong and Bezner-Kerr [46]) in Ghana and Ochieng et al. [41] in Kenya).

Interestingly, Nyantakyi-Frimpong and Bezner-Kerr [46] found that many farmers do not worry about CCV. Instead, intra-household property rights, liberalized markets, and insecure land access are more critical challenges for farmers. This shows that focusing research attention on estimating the impacts of CCV manifestations on RVCs alone, without considering socio-economic dynamics and pressures, may not be an appropriate approach for reducing the vulnerability and increasing the resilience of RVCs in the region.

\subsubsection{Rice Value Chains and Economic Globalization}

This review identifies three themes that appear to have been addressed most intensively in the literature on RVCs and economic globalization in SSA: Limited government support for rice farmers, lack of investment in post-harvesting, and market inefficiency. Here it is suggested that these three themes correspond to three structural limitations that have contributed to RVCs' vulnerability to economic globalization in SSA, as manifested in the difficulty of the rice sector in SSA to respond to growing internal demand for quality rice and to compete in the global market (e.g., Adjao and Staatz [47]; Demont, [31]; Demont and Ndour [1]; Seck et al. [48]).

Various studies have suggested that rice farmers in SSA have been inadequately supported by their respective governments, and that this has effectively left most rice producers in SSA to compete unfairly with producers from other countries where farmers may enjoy greater financial and technological support from their own governments (e.g., Ammani [49]; Aniekwe [50]). The literature points to limited or uncertain access to credit as a problematic area, with poor governments providing limited support to rice producers in Benin and Ghana [51,52]. Other authors have stressed the need for support in the form of programs for technological development [49,53]. Nevertheless, these authors point out that it is not only the level of support, but also governmental intermittence and inconsistency over time that has been problematic for farmers in West Africa [50]. Others have argued that another key aspect is providing adequate support to the usually more marginal and underrepresented small-to-medium-scale rice processors [54].

The second factor in the vulnerability of RVCs to economic globalization in SSA is the lack of investment in key parts of the RVC, particularly post-harvesting processing. Demand for rice has increased steadily over the past decades, but consumers have increasingly sought high-quality rice. RVCs in SSA have often been found incapable of improving the quality of the final product and therefore have failed to compete with high quality imported rice in national markets. Typical value-adding post-harvesting activities include quality upgrading, capacity building, governance, branding, labeling, promotion, and advertising [31]. However, lack of investment in post-harvest rice quality has been a problem in countries such as Senegal, Benin, and Togo [55]. In other countries, such as Nigeria, there are very low levels of on-farm and post-harvest quality-enhancing 
practices [53]. These findings contribute to explaining why domestically processed rice has remained of low quality and has been unattractive, especially to urban rice consumers across SSA countries.

An increased capacity to add value to rice production through post-harvesting processing may help overcome the limitations of market segmentation, which has come to characterize rice markets in SSA. The lack of value-adding to enhance the quality of domestically produced rice in the region has resulted in widespread consumer preference for imported rice, which is perhaps the most important hindrance to the growth of RVCs across SSA. For example, in Ghana, $86 \%$ of rice consumers preferred imported rice, while only $14 \%$ preferred domestically produced rice [56]. Thus, across SSA we see that the inability of the RVC system to tailor the intrinsic and extrinsic quality attributes of domestic rice to urban consumer preferences has put the domestically produced rice at a disadvantage in an import-biased market [1]. This has led to the segmentation of the rice market between imported and domestically produced rice in a number of SSA countries, especially in West Africa [5].

However, evidence indicates that investment in post-harvesting processing has the potential to increase the capacity of RVCs to respond to internal demand and global competition. For example, in Senegal, Demont and colleagues reported that the majority of urban consumers are willing to pay quality premiums for local rice [57,58]. A similar situation was found in Benin [59] and Togo [55]. In most of these countries, rice is parboiled using improved processing technology and is often priced above the rice that is processed using traditional parboilers and milling machines. This observation underscores the importance of enhanced post-harvest processing and its ability to increase the competitiveness of domestic rice across SSA. However, without investment in post-harvest processing and with the removal of state subsidies for fertilizer and modern seeds, privatized extensions, and liberalized prices and imports, the source of domestic commercial rice is left to local private millers. These private millers become the focal point of regional producer-processor rice networks that are unable to improve the processing quality of local rice to attract market domestically and enhance its ability to effectively compete with the imported rice in the region [60].

The third factor of RVC vulnerability to economic globalization in SSA that has been addressed in the literature is market efficiency, or the degree to which markets minimize costs and match supply with demand [61]. Rashid et al. [61] reviewed grain markets in SSA and concluded that "[overall, [...] grain markets are reasonably efficient given the difficult environment in which they operate, but they are constrained by poor infrastructure, administrative and tariff barriers, a high degree of risk and uncertainty, and limited information]" (p. 26). They identify several factors affecting the functioning of markets, including barriers to trade in agriculture (such as district-level taxes, checkpoints, tariffs, and non-tariff barriers to trade, which raise the cost of food in remote deficit areas and landlocked countries), access to information, effectiveness of the legal system, quality of transport infrastructure, regulation of the transport sector, unpredictable food purchases and sales by the government, and foreign exchange controls.

Studies in West Africa point to the deep segmentation of the rice market between local and imported rice, which results in the inability to forward price incentives to producers [5,62]. This is also evident in other areas, including lack of capital access and credit, a non-competitive market for rice, low quality of local milled rice, and price volatility [62].

In sum, the literature on RVCs in SSA has drawn attention to three factors that appear to affect the vulnerability of RVCs to economic globalization, as experienced, for example, through agricultural trade liberalization: Limited government support for rice farmers, lack of investment in post-harvesting processes, and market inefficiency. The evidence suggests that these factors may affect the capacity of RVCs to respond to the pressure of global markets differently, as they hinder the development of technical, knowledge-based, and financial assets that would enable effective responses. In a context in which markets are often working inefficiently due to segmentation and unstable exchange rates, low capacity to respond to global pressures may favor a cycle of increasing marginalization of RVC operators, particularly producers, who find themselves locked in a poverty trap that makes them more vulnerable to climate change as well. 
The level of exposure of RVCs to climatic and economic pressures can vary and in itself depends on economic policies adopted in different countries. Thus the academic debate on the vulnerability of RVCs to climate change and economic globalization in SSA bears a close relationship to the growing scholarship on rural and rice sector development policies in this region.

\subsection{Development Policies and Vulnerability of Rice Value Chains}

This review identified two main foci of research on rice sector development in SSA. First, scholars have debated the advantages and disadvantages of protectionist policies and, conversely, of liberalization measures for rural development and the rice sector. A second focus concerns policies that, regardless of the broader protectionist or liberalized framework, aim to increase capacity and efficiency within rice value chains. In the terms of vulnerability that inform this review, the debate on liberalization and protectionism is relevant because these policies can affect the degree and nature of the exposure of RVCs to economic pressures. On the other hand, the debate on efficiency measures is also relevant because these measures may influence the capacity of RVCs to respond to multiple climatic and economic pressures. This section critically reflects on status of these debates and highlights the most relevant points of contention in relation to the resilience and vulnerability of rice value chains in the region.

In response to the advice of international organizations such as the World Bank and the International Monetary Fund, many governments in SSA have privatized the agri-food sector and have facilitated its opening to global markets as a strategy to increase competition, reduce food prices (especially in urban areas), and mitigate poverty. Various studies have examined such liberalization policies, and while some have shown the advantages of liberalization, others have highlighted its drawbacks. For example, Minot [63] found that food prices were more stable in sub-Saharan countries that were less active in trying to stabilize them, which supports the notion that "regional and international trade can play a useful role in reducing food price volatility, and that traditional food price stabilization efforts may be counterproductive" [63] (p. 45). In a study on Madagascar, Minten et al. [64] find that when the opening of an agri-food market is combined with intensive farm assistance and supervision, global food supply chains can stimulate technology and knowledge transfer through the requirement to comply with high quality and safety standards, which are not required in local markets. Farmers and other operators, therefore, can gain in technology, knowledge productivity, and income from trade liberalization. In Benin, Velde and Maertens [3] report that contract farming increased production levels of local rice and had a positive impact on the welfare of rice-producing farmers. Similarly, in Nigeria, Animashaun et al. [65] and Obi-egbedi et al. [66] suggest that the implementation of a liberalized rice market policy such as opening the market, reducing tariffs and creating an attractive investment environment may encourage direct foreign investment and efficiency in the RVC system, and, in turn, improve the income and wages of smallholder farmers. In a study on Nigeria, Johnson et al. [54] proposed an argument in favor of creating an enabling environment for the private sector to invest in rice processing. Moreover, Van oort et al. [32] argue that while most sub-Saharan countries are far from being self-sufficient in food production, open markets and the expansion of imports will be necessary to fill the consumption-production gap.

However, other studies show the drawbacks of trade liberalization. Coady et al. [67] (p. 721) evaluated tariff reduction in Madagascar and found that "although lowering tariffs generates substantial efficiency gains, these accrue mainly to the top half of the welfare distribution, and poor net sellers are actually worse off". In a study of three West African countries, Moseley et al. [7] (p. 5774) argue that, "although market reforms were intended to improve food production, the result was an increasing reliance on imported rice". On the other hand, some authors have argued with respect to West Africa that despite trade liberalization policies, there is still significant leverage for the protection of national agriculture, and that the withdrawal of agricultural support is due to internal (national and local) issues rather than an international set of players, rules, and interests [4]. 
In fact, protectionist measures, such as subsidies, tariffs and import duties, import restrictions, and import bans, have been widely adopted in SSA. The level of protection varies across countries and agricultural products, mainly with the aim to protect smallholders from being outcompeted by national and international commercial agriculture companies $[6,62,68,69]$. Still, there is often a lack of consensus as to which policy can best reduce or control the exposure to stressors of RVCs in a country. In Nigeria, for example, Ogundere [70] recommends that to increase the competiveness of local rice, the use of tariffs should be encouraged above quantitative restrictions. In contrast, Ammani [49] proposes that restricting rice imports will better improve the ability of smallholders to market rice. Conversely, Maduabuchi and Arene [71] advocate the use of subsidies instead of an outright ban on rice imports, as this may go against a government's position to ensure free trade.

While protectionism and liberalization policies may alter the level and nature of the exposure of RVCs to global economic pressure, scholars have also discussed a different set of policies that address capacity and efficiency within RVCs. In the face of pressures (climatic or economic), these policies have the potential to intervene in the adaptive capacity, rather than in the exposure, of RVCs. In the long term, they may help reduce vulnerability and build resilience.

Calzadilla et al. [72] showed that an increase in agricultural productivity achieves better outcomes than an expansion of irrigated areas as an adaptation strategy for expected climate change effects in SSA. Demont [31] and Demont and Rizzotto [57] proposed a combination of supply- shifting investment, value-adding, and demand-lifting investment policies as options for achieving a self-sufficient rice supply in SSA. Supply-shifting investments address some of the concerns overlooked by both protectionism and liberalization policies. Common supply-lifting investment policies include investment in rice research and technology development, improving crop varieties, optimizing crop types, and extending crop areas and irrigation. These measures will increase rice production and reduce the region's vulnerability to climate change $[30,31,44]$. They do so mainly by boosting the production of local rice through intensification and area expansion, while simultaneously managing yield constraints, such as climate change and soil infertility [73]. In several countries, such as Burkina Faso, Madagascar, Niger, Nigeria, and South Africa, technical and financial assistance may be necessary to reduce the pressures on rice production, especially from climate change. In these countries, policies geared towards investing in irrigation systems, rainwater management, improved crop records, and institutional change, have been called for to minimize the vulnerability of rice production to climate change [30,36,51]. Furthermore, in Benin, Cote d'lvoire, and Ghana, local institutional change, funding, and strengthening farmer group participation through input subsidies and micro-lending in RVC upgrades have all been suggested to enhance rice production, processing, and self-sufficiency $[51,52,60])$.

Value-adding and demand-lifting investment policies seek to enhance rice processing and marketing. According to Demont [31], value-adding and demand-lifting investment policies include processing (milling and parboiling), storage capacity, quality upgrades, capacity building, governance, branding, labeling, identity creation, certification, value chain upgrades, market information systems, market infrastructure, linkages, promotion, advertising, communication, and awareness creation. These modifications are needed to tailor the intrinsic and extrinsic attributes of local rice to consumer preferences and to enhance its competitive ability in a market segmented between local and imported rice [1]. For example, in Burkina Faso, Badolo and Traoré [74] suggest that investment in local rice industries will reduce the vulnerability of rice to the pressures of markets, whereas evidence from the Central African Republic shows that access to marketing along with agricultural extension services has increased the incomes of female households and their livelihoods [75]. In Nigeria, Tiamiyu et al. [53] and Awoyemi [76] suggest that the implementation of policies directed at the promotion of quality-enhancing technologies and investment in storage and processing will increase the quantity of locally processed rice and its ability to compete with imported rice in the Nigerian market. Similarly, in Senegal, Demont et al. [58] reports that investment in post-harvest rice quality is considered a priority in the reversal of urban bias as well as an important step towards achieving the 
self-sufficiency of local markets. In Togo, on the other hand, Fiamohe et al. [55] indicate that investment in quality enhancement is considered to make the consumption of local rice competitive.

In sum, the review of the literature on rice sector development in SSA allows us to make two observations. First, it is apparent that the academic debate on rice development policies, particularly the assessment of different policies and policy approaches (protectionism versus liberalization), strongly depends on the policy objective that is explicitly or implicitly set for rice development policies. Thus, scholars have analyzed policies on improving the self-sufficiency of the national rice sector (Van oort et al. [32]), reducing price volatility (Minot, [63]), supporting low-income farmers (Nicita et al. [68]), or increasing efficiency along the value chain (Demont, [31]). These are distinct policy goals that may result in diverse policies, the assessment of which is therefore highly dependent on the development priorities set for the rice sector in a specific country or region. With respect to the contribution of rice development policies on the vulnerability or resilience of rice value chains in SSA, this literature review does not provide sufficient evidence in support of any specific policy or policy approach in this region. In other words, it is unclear whether and under what conditions the pursuit of a particular policy goal (such as price stabilization or increased efficiency) can contribute to building resilience along the rice value chain.

Second, and in strong connection to the point above, the review of the academic debate on rice development policies has shown that policies create an uneven landscape of "winners" and "losers". In fact, policies may entail trade-offs between social groups or actors along the rice value chain, including between urban consumers and rural producers (Demont [31]; Moseley et al. [7]); between small- and large-scale producers (Colen et al. [77]); between farmers and other actors, such as processors, distributors, or retailers (Becker and Yoboue [60]; Demont and Ndour [1]); or between large and secondary cities (Minot [63]). Again, the social and political prioritization of policy goals is therefore very important in determining who in the rice sector and along the rice value chain benefits from the effects of a particular policy. Thus, protective measures may shield low-income farmers from international competition, but may also result in higher food prices for consumers. Similarly, increasing competition in order to lower food prices may benefit consumers at the expense of other actors along the value chain. While there is often uncertainty around the effects of policies and there is the possibility of counterintuitive results (Garmann [6]), rice development policies that create winners and losers may also create or reinforce an uneven landscape of capacity to respond to climatic and economic disturbances.

\section{Conclusions}

This paper examined the literature on rice value chains in sub-Saharan Africa with the aims of: (i) characterizing the existing research on the vulnerability of rice value chains in SSA; (ii) synthesizing the evidence on the vulnerability of rice value chains to climate change and economic globalization; and (iii) discussing agriculture and rural development policies and their likely effects on the vulnerability of rice value chains.

This review exposed the lack of research on the simultaneous impacts of climate change and trade liberalization on RVCs in SSA. While existing studies have investigated RVCs' vulnerability to individual disturbances, they have mostly failed to analyze how the pressures of climate change and trade liberalization combine and how RVCs respond to such exposures. This is a limitation that hinders the ability to inform policy-making effectively in a context in which RVCs are indeed exposed to multiple pressures. This review also showed the uneven focus on distinct components of RVCs. Studies on vulnerability to climate change mostly address rice production, while studies on trade liberalization tend to address rice production and marketing, giving relatively little attention to other value chain components, such as processing, distribution, and retail. Such an emphasis on production reflects a common bias in food security studies, and overlooks other value chain components that are equally essential in determining the food system outcomes. Future research in SSA should address the impacts of multiple simultaneous pressures on RCVs, while also focusing on 
all the components of the value chain. It is suggested here that a system approach can be an insightful manner to conduct such research. This would entail a solid conceptualization of the food value chain as a socio-ecological system, which will be useful for addressing multiple stressors for livelihoods and food security. Moreover, the adoption of dynamic and participatory modeling approaches, multidimensional conceptual frameworks, and transdisciplinary methodologies may help cross the disciplinary boundaries and build synergies among researchers in the region. All of these areas are almost totally lacking in current research on RVCs in SSA.

This review also showed that there are mixed projections of climate change impacts on RVCs in SSA. We saw that different studies estimate positive or negative effects on future rice production. However, the literature review demonstrated that both observed and projected impacts are greatly uneven geographically, with respect to production systems (especially irrigated versus rainfed systems), and the size of landholdings. Smallholders are expected to bear most of the negative effects of climate change due to their relatively higher sensitivity to such stressors, which is due to their predominantly rainfed production and to lower adaptive capacity caused by poor technological and financial assets.

Future research should address two important research gaps. First, it should focus on particular regions, as climate research is still rather weak across the SSA region. Second, it should examine parts of the value chain other than production. For example, extreme climate events may disrupt not only production but also food processing and distribution. In this respect, it should be reiterated that a system approach that addresses the entirety of the RVC has the potential to significantly improve our understanding of adaptation limitations and needs.

With respect to economic globalization in SSA, this review found that the following themes have been investigated most extensively: limited government support for rice farmers, lack of investment in post-harvesting, and market inefficiency. It was suggested that these three themes correspond to three structural limitations that have contributed to RVCs' vulnerability to economic globalization in SSA, as manifested in the difficulty of the rice sector in SSA to respond to growing internal demands for quality rice and to compete in the global market.

Finally, this review identified two main foci of the debate in the literature on rice sector development, namely the debate on protectionism versus liberalization and the debate on value chain capacity and efficiency. These debates are connected to the literature on the vulnerability of RVCs, as they address issues of exposure to economic disturbances and of RVCs' capacity to adapt to climate and economic disturbances, respectively. While these debates are far from settled, it is apparent that development policies may entail trade-offs and generate uneven landscapes of winners and losers in the RVC, which can significantly affect the vulnerability of different components of the system to contribute to responding to disturbances. It is therefore important that future research on the development of the rice sector, and rural development policy in general in SSA connect climate change and development policy more strongly, and includes considerations of vulnerability and resilience. Future studies can clarify to what extent and in what forms different development policies hinder or enhance the resilience of RVCs to multiple exposures.

Supplementary Materials: Supplementary materials can be found at www.mdpi.com/2225-1154/4/3/47/s1.

Acknowledgments: Fanen Terdoo acknowledges the Tertiary Education Trust Fund (TETFund), Federal University Dutsinma, Katsina State, Nigeria for supporting his ongoing Ph.D. training at the Department of Geography and Environmental Science, University of Reading, United Kingdom.

Author Contributions: Fanen Terdoo and Giuseppe Feola designed the study. Fanen Terdoo selected the literature. Fanen Terdoo (especially Section 3.2) and Giuseppe Feola (especially Section 3.3) conducted the literature review and wrote the article.

Conflicts of Interest: The authors declare no conflicts of interest. 


\section{References}

1. Demont, M.; Ndour, M. Upgrading rice value chains: Experimental evidence from 11 African markets. Glob. Food Secur. 2015, 5, 70-76. [CrossRef]

2. Tollens, E. Markets and institutions for promoting rice as a tool for food security and poverty reduction in sub-Sahara Africa. Afr. Crop Sci. J. 2006, 15, 237-242.

3. Velde, K.V.; Maertens, M. Impact of contract-farming in staple food chains: The case of rice in Benin. In Proceedings of the Agri-Food and Rural Innovations for Healthier Societies, Ljubljana, Slovenia, 26-29 August 2014.

4. Laroche, D.C.; Postolle, A. Food sovereignty and agricultural trade policy commitments: How much leeway do West African nations have? Food Policy 2013, 38, 115-125. [CrossRef]

5. Del Villar, P.M.; Lançon, F. West African rice development: Beyond protectionism versus liberalization? Glob. Food Secur. 2015, 5, 56-61. [CrossRef]

6. Garmann, S. Does globalization influence protectionism? Empirical evidence from agricultural support. Food Policy 2014, 49, 281-293. [CrossRef]

7. Moseley, W.G.; Carney, J.; Becker, L. Neoliberal policy, rural livelihoods, and urban food security in West Africa: A comparative study of The Gambia, Cote d'Ivoire, and Mali. Proc. Natl. Acad. Sci. USA 2010, 107, 5774-5779. [CrossRef] [PubMed]

8. Barrett, C.B. Smallholder market participation: Concepts and evidence from eastern and southern Africa. Food Policy 2008, 33, 299-317. [CrossRef]

9. Niang, I.; Ruppel, O.C.; Abdrabo, M.A.; Essel, A.; Lennard, C.; Padgham, J.; Urquhart, P. Africa. In Climate Change 2014: Impacts, Adaptation and Vulnerability-Contributions of the Working Group II to the Fifth Assessment Report of the Intergovernmental Panel on Climate Change; Barros, V.R., Field, C.B., Dokken, D.J., Mastrandrea, M.D., Mach, K.J., Bilir, T.E., Chatterjee, M., Ebi, K.L., Estrada, Y.O., Genova, R.C., Eds.; Cambridge University Press: New York, NY, USA, 2014; pp. 1199-1265.

10. Roudier, P.; Sultan, B.; Quirion, P.; Berg, A. The impact of future climate change on West African crop yields: What does the recent literature say? Glob. Environ. Chang. 2011. [CrossRef]

11. Ericksen, P.J. Conceptualizing food systems for global environmental change research. Glob. Environ. Chang. 2008, 18, 234-245. [CrossRef]

12. Ingram, J. A food systems approach to researching food security and its interactions with global environmental change. Food Secur. 2011, 3, 417-431. [CrossRef]

13. Tendall, D.M.; Joerin, J.; Kopainsky, B.; Edwards, P.; Shreck, A.; Le, Q.B.; Kruetli, P.; Grant, M.; Six, J. Food system resilience: Defining the concept. Glob. Food Secur. 2015, 6, 17-23. [CrossRef]

14. Scoones, I.; Leach, M.; Smith, A.; Stagl, S.; Stirling, A.; Thompson, J. Dynamic Systems and the Challenge of Sustainability; STEPS Centre: Brighton, UK, 2007.

15. Thompson, J.; Scoones, I. Addressing the dynamics of agri-food systems: An emerging agenda for social science research. Environ. Sci. Policy 2009, 12, 386-397. [CrossRef]

16. Kaplinsky, R.; Morris, M. A Handbook for Value Chain Research; IDRC: Ottawa, ON, Canada, 2000.

17. Stave, K.A.; Kopainsky, B. A system dynamics approach for examining mechanisms and pathways of food supply vulnerability. J. Environ. Stud. Sci. 2015, 5, 321-336. [CrossRef]

18. Gallopín, G.C. Linkages between vulnerability, resilience, and adaptive capacity. Glob. Environ. Chang. 2006, 16, 293-303. [CrossRef]

19. Resilience and Vulnerability: Complementary or Conflicting Concepts? Available online: http://www. ecologyandsociety.org/vol15/iss3/art11/ (accessed on 6 August 2016).

20. Adger, W.N. Vulnerability. Glob. Environ. Chang. 2006, 16, 268-281. [CrossRef]

21. Ericksen, P.J.; Ingram, J.S.I.; Liverman, D.M. Food security and global environmental change: Emerging challenges. Environ. Sci. Policy 2009, 12, 373-377. [CrossRef]

22. What Is the Vulnerability of a Food System to Global Environmental Change? Available online: http:/ /www.ecologyandsociety.org/vol13/iss2/art14/ (accessed on 6 August 2016).

23. Stave, K.A.; Kopainsky, B. Dynamic thinking about food system vulnerabilities in highly developed countries: Issues and initial analytic structure for building resilience. In Proceedings of the 32nd International Conference of the System Dynamics Society, Delft, The Netherlands, 20-24 July 2014. 
24. Leichenko, R.; O’Brien, K. Environmental Change and Globalization: Double Exposures; Oxford University Press: New York, NY, USA, 2008.

25. Luers, A.L.; Lobell, D.B.; Sklar, L.S.; Addams, C.L.; Matson, P.A. A method for quantifying vulnerability, applied to the agricultural system of the Yaqui Valley, Mexico. Glob. Environ. Chang. 2003, 13, 255-267. [CrossRef]

26. Mertz, O.; Mbow, C.; Reenberg, A.; Diouf, A. Farmers' perceptions of climate change and agricultural adaptation strategies in rural sahel. Environ. Manag. 2009, 43, 804-816. [CrossRef] [PubMed]

27. Feola, G.; Lerner, A.M.; Jain, M.; Montefrio, M.J.F.; Nicholas, K.A. Researching farmer behaviour in climate change adaptation and sustainable agriculture: Lessons learned from five case studies. J. Rural Stud. 2015, 39, 74-84. [CrossRef]

28. Feola, G.; Agudelo, V.L.A.; Contesse, B.P. Colombian agriculture under multiple exposures: A review and research agenda. Clim. Dev. 2015, 7, 278-292. [CrossRef]

29. Brown, K. Sustainable adaptation: An oxymoron? Clim. Dev. 2011, 3, 21-31. [CrossRef]

30. Saito, K.; Dieng, I.; Toure, A.A.; Somado, E.A.; Wopereis, M.C.S. Rice yield growth analysis for 24 African countries over 1960-2012. Glob. Food Secur. 2014, 2008, 1-8. [CrossRef]

31. Demont, M. Reversing urban bias in African rice markets: A review of 19 national rice development strategies. Glob. Food Secur. 2013, 2, 172-181. [CrossRef]

32. Van Oort, P.A.J.; Saito, K.; Tanaka, A.; Amovin-Assagba, E.; van Bussel, L.G.J.; van Wart, J.; de Groot, H.; van Ittersum, M.K.; Cassman, K.G.; Wopereis, M.C.S. Assessment of rice self-sufficiency in 2025 in eight African countries. Glob. Food Secur. 2015. [CrossRef]

33. Knox, J.; Hess, T.; Daccache, A.; Wheeler, T. Climate change impacts on crop productivity in Africa and South Asia. Environ. Res. Lett. 2012. [CrossRef]

34. Liersch, S.; Cools, J.; Kone, B.; Koch, H.; Diallo, M.; Reinhardt, J.; Fournet, S.; Aich, V.; Hattermann, F.F. Vulnerability of rice production in the Inner Niger Delta to water resources management under climate variability and change. Environ. Sci. Policy 2013, 34, 18-33. [CrossRef]

35. Kima, A.S.; Traore, S.; Wang, Y.M.; Chung, W.G. Multi-genes programing and local scale regression for analyzing rice yield response to climate factors using observed and downscaled data in Sahel. Agric. Water Manag. 2014, 146, 149-162. [CrossRef]

36. Rowhani, P.; Lobell, D.B.; Linderman, M.; Ramankutty, N. Climate variability and crop production in Tanzania. Agric. For. Meteorol. 2011, 151, 449-460. [CrossRef]

37. Ward, P.S.; Florax, R.J.G.M.; Flores-Lagunes, A. Climate change and agricultural productivity in Sub-Saharan Africa: A spatial sample selection model. Eur. Rev. Agric. Econ. 2014, 41, 199-226. [CrossRef]

38. Nwalieji, H.U.; Uzuegbunam, C.O. Effect of climate change on rice production in Anambra State, Nigeria. J. Agric. Ext. 2012, 16, 81-91. [CrossRef]

39. Calzadilla, A.; Zhu, T.; Rehdanz, K.; Tol, R.S.J.; Ringler, C. Climate change and agriculture: Impacts and adaptation options in South Africa. Water Resour. Econ. 2014, 5, 24-48. [CrossRef]

40. Harvey, C.A.; Rakotobe, Z.L.; Rao, N.S.; Dave, R.; Razafimahatratra, H.; Rabarijohn, R.H.; Rajaofara, H.; Mackinnon, J.L. Extreme vulnerability of smallholder farmers to agricultural risks and climate change in Madagascar. Philos. Trans. R. Soc. Lond. B Biol. Sci. 2014. [CrossRef] [PubMed]

41. Ochieng, J.; Kirimi, L.; Mathenge, M. Effects of climate variability and change on agricultural production: The case of small scale farmers in Kenya. J. Life Sci. 2016. [CrossRef]

42. Ayinde, O.E.; Ojehomon, V.E.T.; Daramola, F.S.; Falaki, A.A. Evaluation of the effects of climate change on rice production in Niger State, Nigeria. Ethiop. J. Environ. Stud. Manag. 2013, 6, 763-773. [CrossRef]

43. Ajetomobi, J.; Abiodun, A.; Hassan, R. Economic impact of climate change on irrigated rice agriculture in Nigeria. In Proceedings of the Joint 3rd African Association of Agricultural Economists (AAAE) and 48th Agricultural Economists Association of South Africa (AEASA) Conference, Cape Town, South Africa, 19-23 September 2010.

44. Liu, J.; Fritz, S.; van Wesenbeeck, C.F.A.; Fuchs, M.; You, L.; Obersteiner, M.; Yang, H. A spatially explicit assessment of current and future hotspots of hunger in Sub-Saharan Africa in the context of global change. Glob. Planet. Chang. 2008, 64, 222-235. [CrossRef]

45. Lobell, D.B.; Burke, M.B.; Tebaldi, C.; Mastrandrea, M.D.; Falcon, W.P.; Naylor, R.L. Prioritizing climate change adaptation needs for food security in 2030. Science 2008, 319, 607-610. [CrossRef] [PubMed] 
46. Nyantakyi-Frimpong, H.; Bezner-Kerr, R. The relative importance of climate change in the context of multiple stressors in semi-arid Ghana. Glob. Environ. Chang. 2015, 32, 40-56. [CrossRef]

47. Adjao, R.T.; Staatz, J.M. Asian rice economy changes and implications for sub-Saharan Africa. Glob. Food Secur. 2014. [CrossRef]

48. Seck, P.A.; Tollens, E.; Wopereis, M.C.S.; Diagne, A.; Bamba, I. Rising trends and variability of rice prices: Threats and opportunities for sub-Saharan Africa. Food Policy 2010, 35, 403-411. [CrossRef]

49. Ammani, A.A. Impact of market-determined exchange rates on rice production and import in Nigeria. Int. J. Food Agric. Econ. 2013, 1, 85-98.

50. Aniekwe, C. Agricultural trade liberalization and small-holder development: West African rice farmers in perspective. In Proceedings of the Second Africa Rice Congress, Bamako, Mali, 22-26 March 2010.

51. Totin, E.; van Mierlo, B.; Saïdou, A.; Mongbo, R.; Agbossou, E.; Stroosnijder, L.; Leeuwis, C. Barriers and opportunities for innovation in rice production in the inland valleys of Benin. J. Life Sci. 2012. [CrossRef]

52. Mumuni, E.; Oladele, O.I. Farmers' assessment of donor support for rain-fed Lowland rice production in Ashanti and Northern Regions in Ghana. Life Sci. J. 2012, 9, 377-381.

53. Tiamiyu, S.A.; Usman, A.; Ugalahi, U.B. Adoption of on-farm and post-harvest rice quality enhancing technologies in Nigeria. Tropicultura 2014, 32, 67-72.

54. Johnson, M.; Takeshima, H.; Gyimah-brempong, K.; Kuku-shittu, O.; Diao, W.X.; Dorosh, P.; Malek, M.; Koo, J.; Pradesha, A.; Ajibola, A. Assessing the Potential and Policy Alternatives for Achieving Rice Competitiveness and Growth in Nigeria; International Food Policy Research Institute: Washington, DC, USA, 2015.

55. Fiamohe, R.; Nakelse, T.; Diagne, A.; Seck, P.A. Assessing the effect of consumer purchasing criteria for types of rice in Togo: A choice modeling approach. Agribusiness 2014. [CrossRef]

56. Tomlins, K.I.; Manful, J.T.; Larwer, P.; Hammond, L. Urban consumer preferences and sensory evaluation of locally produced and imported rice in West Africa. Food Qual. Preference 2005, 16, 79-89. [CrossRef]

57. Demont, M.; Rizzotto, A.C. Policy Sequencing and the Development of Rice Value Chains in Senegal. Dev. Policy Rev. 2012, 30, 451-472. [CrossRef]

58. Demont, M.; Rutsaert, P.; Ndour, M.; Verbeke, W. Reversing urban bias in African rice markets: Evidence from Senegal. World Dev. 2013, 45, 63-74. [CrossRef]

59. Demont, M.; Zossou, E.; Rutsaert, P.; Ndour, M.; van Mele, P.; Verbeke, W. Consumer valuation of improved rice parboiling technologies in Benin. Food Qual. Preference 2012, 23, 63-70. [CrossRef]

60. Becker, L.; Yoboue, N.G. Rice producer-processor networks in Cote d'lvoire. Am. Geogr. Soc. 2009, 99, 164-185.

61. Rashid, S.; Minot, N.; Lemma, S.; Behute, B. Are staple food markets in Africa efficient? Spatial Price Analyses and Beyond. In Proceedings of the COMESA Policy Seminar "Food Price Variability: Causes, Consequences, and Policy Options", Maputo, Mozambique, 25-26 January 2010.

62. Katic, P.G.; Namara, R.E.; Hope, L.; Owusu, E.; Fujii, H. Rice and irrigation in West Africa: Achieving food security with agricultural water management strategies. Water Resour. Econ. 2013, 1, 75-92. [CrossRef]

63. Minot, N. Food price volatility in sub-Saharan Africa: Has it really increased? Food Policy 2014, 45, 45-56. [CrossRef]

64. Minten, B.; Randrianarison, L.; Swinnen, J.F.M. Global retail chains and poor farmers: Evidence from Madagascar. World Dev. 2009, 37, 1728-1741. [CrossRef]

65. Animashaun, J.O.O.; Titilayo, V.E.; Muhammad-Lawal, A.; Amolegbe, K.B. Between foreign direct investment (FDI) and outsourcing: Which policy strategy will enhance the competiveness of the Nigerian rice setor? Int. J. Food Agric. Econ. 2015, 3, 91-105.

66. Obi-Egbedi, O.; Okoruwa, V.O.; Yusuf, S.A.; Kemisola, O. Rice trade protectionism versus liberalization in Nigeria: A CGE analysis of economic and welfare effects. In Proceedings of the 4th International Conference of the African Association of Agricultural Economists, Hammamet, Tunisia, 22-25 September 2013.

67. Coady, D.; Dorosh, P.; Minten, B. Evaluating alternative policy responses to higher world food prices: The case of increasing rice prices in Madagascar. Am. J. Agric. Econ. 2009, 91, 711-722. [CrossRef]

68. Nicita, A.; Olarreaga, M.; Porto, G. Pro-poor trade policy in sub-Saharan Africa. J. Int. Econ. 2014, 92, $252-265$. [CrossRef]

69. Obi-Egbedi, O.; Okoruwa, V.O.; Aminu, A.; Yusuf, S. Effect of rice trade policy on household welfare in Nigeria. Eur. J. Bus. Manag. 2012, 4, 160-171. 
70. Ogundere, F. Trade liberalization and import demand for rice in Nigeria: A dynamic modelling. J. Econ. Rural Dev. 2007, 16, 34-45.

71. Maduabuchi, M.; Arene, C.J. Trade liberalization, exchange rate changes, and the competitiveness of carbohydrate staple markets in Nigeria. Int. J. Agric. Manag. Dev. 2012, 2, 121-136.

72. Calzadilla, A.; Zhu, T.; Rehdanz, K.; Tol, R.S.J.; Ringler, C. Economywide impacts of climate change on agriculture in Sub-Saharan Africa. Ecol. Econ. 2013, 93, 150-165. [CrossRef]

73. Rodenburg, J.; Zwart, S.J.; Kiepe, P.; Narteh, L.T.; Dogbe, W.; Wopereis, M.C.S. Sustainable rice production in African inland valleys: Seizing regional potentials through local approaches. Agric. Syst. 2014, 123, 1-11. [CrossRef]

74. Badolo, F.; Traore, F. Impact of Rising World Rice Prices on Poverty and Inequality in Burkina Faso; E 2012.22; Cerdi Etudes \& Documents: Clermont-Ferrand, France, 2012; pp. 1-39.

75. Mbétid-Bessane, E. Adoption et intensification du Nouveau Riz pour l'Afrique en Centrafrique. Tropicultura 2014, 32, 16-21.

76. Awoyemi, T.T. Explaining rice price shocks in Nigeria: Implications for policy intervention. Rural Econ. Dev. 2004, 18, 46-52.

77. Colen, L.; Demont, M.; Swinnen, J. Smallholder participation in value chains: The case of domestic rice in Senegal. In Rebuilding West Africa's Food Potential; IFAD: Rome, Italy, 2013; pp. 391-415.

(c) 2016 by the authors; licensee MDPI, Basel, Switzerland. This article is an open access article distributed under the terms and conditions of the Creative Commons Attribution (CC-BY) license (http:/ / creativecommons.org/licenses/by/4.0/). 